\title{
FOLIAR CONTENTS IN BABYCORN AND CHEMICAL ATTRIBUTES OF AN OXISOL UNDER APPLICATION OF SWINE WASTEWATER ${ }^{1}$
}

\author{
Adriana Maria Meneghetti², Lúcia Helena Pereira Nóbrega ${ }^{3}$, Silvio Cesar Sampaio ${ }^{4}$ e Rafael Gil Ferques ${ }^{5}$
}

\begin{abstract}
This objective of this study was to evaluate the influence of swine wastewater (ARS), applied alone and in combination with nitrogen fertilizer $(\mathrm{AD})$, on foliar concentrations of macronutrients $\left(\mathrm{N}_{\text {total }}, \mathrm{P}, \mathrm{K}, \mathrm{Ca}, \mathrm{Mg}\right.$ and $\left.\mathrm{S}\right)$ and micronutrients $(\mathrm{Cu}$, $\mathrm{Zn}, \mathrm{Mn}$ and $\mathrm{Fe})$, as well as chemical attributes of an Oxisol $\left(\mathrm{pH}\right.$, potential acidity $\left(\mathrm{H}+\mathrm{A} \ell^{+3}\right)$, organic matter $(\mathrm{OM})$, cation exchange capacity (CEC), base saturation (V), Ca, Mg, K, P, Na, sodium adsorption ratio (SAR) and exchangeable sodium percentage (ESP) on the cultivation of baby corn. For this purpose an experiment was conducted at the State University of Western Parana in a completely randomized design with eight treatments and three replications, consisting of a 4 x 2 factorial arrangement with the application of four swine manure wastewater doses $\left(0,40,80\right.$ and $120 \mathrm{~kg} \mathrm{ha}^{-1}$ of $\left.\mathrm{N}\right)$ prior to sowing and two levels of $\mathrm{AD}\left(0\right.$ and $\left.40 \mathrm{~kg} \mathrm{ha}^{-1}\right)$ as urea at sowing and in coverage. Soil samples were collected at a depth of 0-60 cm during three periods: before sowing and application of the ARS, at the middle and at the end of the cycle. The results were subjected to analysis of variance at $5 \%$ probability, and they indicated that the application of ARS combined with AD resulted in increases to the soil chemical properties: $\mathrm{H}+\mathrm{A} \ell^{+3}, \mathrm{CTC}, \mathrm{V}, \mathrm{P}, \mathrm{K}, \mathrm{Ca}$ and $\mathrm{Mg}$, decreases in $\mathrm{pH}$, organic matter and PST, and consistent values for RAS. For the foliar nutrient concentrations there was an increase in fertilization using wastewater from swine manure which resulted in significant differences for foliar concentrations of $\mathrm{N}$ and $\mathrm{P}$ in babycorn; it also promoted lower levels than adequate for $\mathrm{N}$ and $\mathrm{K}$, and appropriate levels of $\mathrm{Cu}, \mathrm{Zn}, \mathrm{Mn}$ and Fe. Concentrations of ARS should be less than $345 \mathrm{~m}^{3} \mathrm{ha}^{-1}$ when applied alone, or when combined with AD should be less than $120 \mathrm{~kg} \mathrm{ha}^{-1}$ of N, since systematic use elevated levels of plant nutrients ( $\mathrm{P}, \mathrm{Ca}, \mathrm{Mg}$ and $\mathrm{S}$ ), suggesting their accumulation.
\end{abstract}

Key words: Zea mays L., soil quality, waste use

\section{RESUMO}

\section{TEORES FOLIARES NO MINIMILHO E ATRIBUTOS QUÍMICOS DE SOLO SOB APLICAÇÃO DE ÁGUA RESIDUÁRIA DE SUINOCULTURA}

O objetivo deste trabalho foi avaliar a influência de doses de água residuária de suinocultura (ARS), aplicados de forma isolada e combinada com adubação nitrogenada (AD), sobre os teores foliares de macronutrientes $\left(\mathrm{N}_{\text {total }}, \mathrm{P}, \mathrm{K}, \mathrm{Ca}, \mathrm{Mg}\right.$ e $\mathrm{S})$, micronutrientes $(\mathrm{Cu}, \mathrm{Zn}, \mathrm{Mn}$ e $\mathrm{Fe}$,) e atributos químicos de um LATOSSOLO VERMELHO. Analisou-se o pH, acidez potencial $\left(\mathrm{H}+\mathrm{A} \ell^{+3}\right)$, matéria orgânica $(\mathrm{MO})$, capacidade de troca de cátions $(\mathrm{CTC})$, saturação por bases $(\mathrm{V})$, Ca, $\mathrm{Mg}, \mathrm{K}, \mathrm{P}, \mathrm{Na}$, razão de adsorção de sódio (RAS) e porcentagem de sódio trocável (PST) na cultura de minimilho. Para isso, foi conduzido experimento na Universidade Estadual do Oeste do Paraná em delineamento experimental inteiramente casualizado, com oito tratamentos e três repetições, dispostos em esquema fatorial 4 x 2, os quais consistiram da aplicação, anterior à semeadura de quatro doses de $\operatorname{ARS}\left(0,40,80\right.$ e $120 \mathrm{~kg} \mathrm{ha}^{-1}$ de $\left.\mathrm{N}\right)$ e duas doses de $\mathrm{AD}\left(0\right.$ e $\left.40 \mathrm{~kg} \mathrm{ha}^{-1}\right)$, na forma de ureia na semeadura e também como cobertura. As amostras de solo foram coletadas na profundidade de 0-60 $\mathrm{cm}$ em três períodos: antes da semeadura e aplicação da ARS, meio e final do ciclo da cultura. Os resultados foram submetidos à análise de variância a 5\% de probabilidade, e indicaram que a aplicação de ARS combinada com AD proporcionou acréscimo nos atributos químicos do solo: $\mathrm{H}+\mathrm{A} \ell^{+3}, \mathrm{CTC}, \mathrm{V}, \mathrm{P}, \mathrm{K}, \mathrm{Ca}$ e Mg; decréscimos nos valores de pH, MO e PST; mantendo constante os valores para RAS. Para os teores foliares houve incremento com a adubação com ARS resultando em diferenças significativas para os teores foliares para $\mathrm{N}$ e $\mathrm{P}$; também proporcionou teores abaixo dos adequados para $\mathrm{N}$ e $\mathrm{K}$, dentro dos teores adequados para $\mathrm{Cu}, \mathrm{Zn}, \mathrm{Mn}$ e Fe. As doses de ARS devem ser menores que $345 \mathrm{~m}^{3}$ ha $^{-1}$ quando aplicadas isoladamente, ou, quando combinadas com $\mathrm{AD}$, menores que $120 \mathrm{~kg} \mathrm{ha}^{-1} \mathrm{de} \mathrm{N}$, pois o uso sistemático elevou os teores de nutrientes na planta (P, Ca, Mg e S), sugerindo acúmulo dos mesmos.

Palavras chave: Zea mays L., qualidade do solo, uso de dejetos

\section{Recebido para publicação em 05/01/2013. Aprovado em 08/11/2013.}

1- Parte da Tese de Doutorado defendida pelo primeiro autor;

2 - Quimica, Pós-doutorado em Engenharia Agrícola, UNIOESTE - PNPD/CAPES. E-mail: adri@innet.com.br.

3 - Eng. Agrônoma, Profa. Associada UNIOESTE/CASCAVEL/PGEAGRI/RHESA. E-mail: lucia.nobrega@unioeste.br

4 - Eng. Agrícola, Prof. Associado UNIOESTE/CASCAVEL/PGEAGRI/RHESA. E-mail: silvio.sampaio@unioeste.br.

5 - Graduado em Sistemas de Informação, FAG/CASCAVEL. E-mail: ferques@yahoo.com.br.

574 REVENG 574-582p.

ENGENHARIA NA AGRICULTURA, VIÇOSA - MG, V.21 N.6, NOVEMBRO / DEZEMBRO 2013 


\section{INTRODUCTION}

Swine farming is prominent in western Paraná. Although it positively adds value to the property, it presents the negative aspect of being a large waste generator. Thus, alternatives allowing for the use of these wastes are needed, both environmentally and economically.

The environmental impact of using nutrient sources applied during medium- and long-term periods can be evaluated by using the integrated attributes that take into account harmful or beneficial effects of waste as a source of nutrients to plants when applied in soil management systems (PANDOLFO et al., 2008).

Konzen and Alvarenga (2008) studied the cerrado soil profile when applying swine slurry concentrations of 45,90 and $135 \mathrm{~m}^{3} \mathrm{ha}^{-1}$ for three successive years, covering $0-20,20-40$ and $40-60 \mathrm{~cm}$. The authors verified no differences in concentrations of phosphorus, potassium, magnesium, calcium, copper and zinc, as well as no variation for organic matter, phosphorus, potassium. Magnesium and calcium showed similar behavior in all treatments; however, there was an increase of copper and zinc in the deeper layers, causing concerns of environmental safety.

After application of the swine slurry on clay soil, Shen and Shen (2001) observed a decrease in aluminum content and increased $\mathrm{pH}$ of the soil, as well as increased levels of phosphorus, calcium and potassium in the leaves of bean crops, which suggests a beneficial effect of the organic fertilizer in reducing soil aluminum with improved animal nutrition.

The nutritional needs of any plant are determined by the amount of nutrients it extracts during its cycle (BÜLL, 1993) and these vary depending on the plant produced and its interaction with the environment. Determination of nutritional requirements is based on the expected correlation between the availability of nutrients in the soil, foliar content and productivity (MALAVOLTA et al., 1997). Studies have shown that application of wastewater increased the concentration of macro and micronutrients in various crops such as cotton (FERREIRA et al., 2005), horticulture (BAUMGARTNER et al., 2007) and maize (PRIOR, 2008), where the increase was influenced by the concentration of nutrients in the wastewater.

Swine farming is considered a wasteconcentrating activity with high pollutant load to the soil, air and water, and in some regions of Brazil, there was considerable increase in production of swine wastewater (ARS) with intensified technical swine farming, since depending on the type of management it becomes a major source of contamination. Therefore, alternatives are sought that allow for waste utilization, minimizing its impact on the environment (SMANHOTTO et al., 2010).

Brandjes et al. (1996) stressed that the swine wastes are composed of elements that both promote plant growth and cause environmental damage. Hence the importance of assessing how much and for how long it can be added to the soil without any negative consequences, such as ionic imbalance, phytotoxicity to plants, atmosphere pollution by volatilization and contamination of surface and subsurface waters by leaching, so that systems fertilized with the waste become self-sustaining.

Successive application of the swine slurry to soil over a long period of time (four years) can produce, in addition to beneficial effects, adverse effects on soil properties such as mineralization of soil organic carbon due to high microbial oxidation. Compared with mineral fertilizer and a control, soils treated with swine manure were characterized by higher microbial biomass and enzymatic activities, lower total organic carbon contents and metabolic quotient, and higher values of $\mathrm{pH}$, electrical conductivity, and available phosphorus and potassium contents, attributed to high levels of $\mathrm{CaCO}_{3}$ and soluble salts in the swine waste (PLAZA et al., 2004).

Therefore, it is imperative to define and adopt criteria to ensure the safety of using agricultural waste and ensure a sustainable and lasting relationship between the waste management used, swine farmers and farmers overall.

The amounts and frequencies with which animal manure can be applied to the soil vary with the soil type, nature and composition of the waste, climatic conditions and crop species (BARROS et al., 2005). The residue dose is determined based on the nutrient with highest concentration, which is usually nitrogen.

In this context, the objective of the present study was to evaluate the effect of using swine wastewater alone and when combined with nitrogen fertilization on the nutritional status of plants and chemical characteristics of soil cultivated with baby corn after the sixth cycle of swine wastewater application. 


\section{MATERIALS AND METHODS}

The experiment was conducted at the Experimental Center of Agricultural Engineering NEEA, Center for Science and Technology, State University of Parana - Campus of Cascavel, PR, located at $\mathrm{km} 101$ of BR 467 in the direction of Cascavel - Toledo, at the coordinates $24^{\circ} 48^{\prime}$ south latitude and $53^{\circ} 26^{\prime}$ 'west longitude, and elevation of $760 \mathrm{~m}$, from October to December 2008. The climate is humid subtropical (Cfa), with $1800 \mathrm{~mm}$ of average annual rainfall. The soil is defined as Oxisol according to the classification of Embrapa (2006).

Treatments were arranged in a completely randomized design according to the soil conditions in a $4 \times 2$ factorial arrangement (four doses of swine wastewater - ARS and 2 doses of nitrogen fertilizer (AD)), with three replicates consisting of ARS doses $\left(0,115.20,230.40\right.$ and $345.60 \mathrm{~m}^{3} \mathrm{ha}^{-1}$ or $0,40,80$ and $120 \mathrm{~kg} \mathrm{ha}^{-1}$ of $\left.\mathrm{N}\right)$ and AD levels (0 and $\left.40 \mathrm{~kg} \mathrm{ha}^{-1}\right)$, totaling eight treatments with three replicates each.

The average chemical characteristics of the soil for the depth of $0-60 \mathrm{~cm}$ at the beginning of the experimental are presented in Table 1. The ARS used was collected from a rural property with an integrated biosystem for waste treatment and handling in a piglet production unit (PPU). The ARS collection point was the discharge pipe, after which it had passed through the biodigester, followed by a sedimentation tank and stabilization pond (characterization - Table 2).

Table 1. Chemical characterization of the soil before swine wastewater application: values of $\mathrm{pH}$, organic matter $(\mathrm{OM})$, phosphorus $(\mathrm{P})$, potential acidity $\left(\mathrm{H}+\mathrm{A} \ell^{+3}\right)$, cation exchange capacity (CEC), calcium $\left(\mathrm{Ca}^{+2}\right)$, magnesium $\left(\mathrm{Mg}^{+2}\right)$, potassium $\left(\mathrm{K}^{+1}\right)$, sodium adsorption ratio (SAR), saturation (V\% and exchangeable sodium percentage (ESP). NEEA, Cascavel - PR, 2008

\begin{tabular}{|c|c|c|c|c|c|c|c|c|c|c|c|c|}
\hline \multirow{2}{*}{$\mathrm{T}$} & \multirow{2}{*}{$\begin{array}{c}\mathrm{pH} \\
\left(\mathrm{CaCl}_{2}\right)\end{array}$} & \multirow[t]{2}{*}{$\begin{array}{c}\mathrm{MO} \\
\left(\mathrm{g} \mathrm{dm}^{-3}\right)\end{array}$} & \multirow[t]{2}{*}{$\begin{array}{c}\mathrm{P} \\
\left(\mathrm{mg} \mathrm{dm}^{-3}\right)\end{array}$} & $\mathrm{H}+\mathrm{A} \ell^{+3}$ & $\mathrm{CTC}$ & $\mathrm{Ca}$ & $\mathrm{Mg}$ & K & $\mathrm{Na}$ & \multirow{2}{*}{$\begin{array}{c}\text { RAS } \\
\left(\mathrm{cmol} \mathrm{L}^{-1}\right)^{y^{2}}\end{array}$} & $\mathrm{~V}$ & PST \\
\hline & & & & \multicolumn{6}{|c|}{ 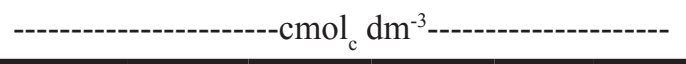 } & & \multicolumn{2}{|c|}{-----V(\%)----- } \\
\hline 1 & 6.17 & 19.95 & 8.80 & 3.32 & 13.14 & 3.29 & 2.88 & 0.31 & 0.23 & 0.13 & 75.15 & 33.93 \\
\hline 2 & 6.20 & 22.15 & 7.23 & 3.30 & 12.66 & 5.01 & 2.10 & 0.24 & 0.20 & 0.10 & 74.02 & 18.76 \\
\hline 3 & 6.27 & 23.12 & 3.50 & 3.07 & 11.67 & 3.21 & 2.47 & 0.26 & 0.23 & 0.14 & 73.82 & 29.29 \\
\hline 4 & 6.37 & 21.99 & 5.83 & 3.04 & 11.64 & 3.66 & 2.39 & 0.22 & 0.20 & 0.11 & 73.70 & 23.14 \\
\hline 5 & 6.73 & 22.46 & 7.77 & 2.34 & 13.29 & 5.06 & 2.54 & 0.36 & 0.26 & 0.12 & 81.87 & 30.01 \\
\hline 6 & 6.27 & 23.60 & 5.73 & 2.98 & 13.08 & 4.08 & 2.78 & 0.24 & 0.23 & 0.13 & 77.06 & 31.14 \\
\hline 7 & 6.47 & 24.32 & 7.90 & 2.80 & 12.71 & 4.38 & 2.56 & 0.31 & 0.23 & 0.12 & 77.32 & 26.25 \\
\hline 8 & 6.43 & 21.71 & 6.33 & 2.84 & 13.13 & 4.64 & 2.66 & 0.33 & 0.23 & 0.12 & 77.70 & 25.23 \\
\hline
\end{tabular}

Table 2. Physico-chemical characterization of swine wastewater used in the experiment. Cascavel - PR, 2008

\begin{tabular}{lclc}
\hline \multicolumn{1}{c}{ Parameters } & Result & \multicolumn{1}{c}{ Parameters } & Result \\
\hline $\mathrm{pH}^{*}$ & 7.92 & Copper & 12.50 \\
Total nitrogen & 338.80 & Zinc & 76.50 \\
Nitrate & 8.00 & Iron & 75.00 \\
Nitrite & 0.40 & Manganese & 16.50 \\
total phosphorus & 21.13 & Fixed solids & 729.00 \\
Potassium & 2.00 & settleable solids & 6.50 \\
Sodium & 1.00 & total solids & 1.481 .00 \\
Calcium & 2.25 & Total volatile solids & 671.00 \\
Magnesium & 0.95 & & \\
\hline
\end{tabular}

* $\mathrm{pH}$ determined in $\mathrm{CaCl}_{2}$, the other parameters were measured in $\mathrm{mg} \mathrm{L}^{-1}$. 
After ARS application, baby corn seeding (variety BR 106 - EMBRAPA Maize and Sorghum) was performed manually in tillage on october 13 , 2008, with $0.50 \mathrm{~m}$ spacing between rows and 0.08 $\mathrm{m}$ between plants at $0.04 \mathrm{~m}$ deep. Emergence occurred seven days after sowing (DAS). In the growth stage (ii) when plants presented three fully expanded leaves (12 DAS), manual thinning was performed to adjust the population to 180,000 plants per hectare and density of 10 plants per linear meter.

At appearance of female inflorescence, R1 stage (MAGALHÃES; DURÃES, 2006), the leaf located opposite and below the first spike was removed from three plants per plot, considering the middle third and excluding the central rib (MALAVOLTA, et al., 1997), for purposes of leaf analysis. Determination of $\mathrm{N}, \mathrm{P}, \mathrm{K}, \mathrm{Ca}, \mathrm{Mg}, \mathrm{S}, \mathrm{Cu}$, $\mathrm{Zn}, \mathrm{Mn}$ and $\mathrm{Fe}$ was performed according to the methodology proposed by Tedesco et al. (1995), Laboratory of Environmental Sanitation (LASAM), Center for Exact Sciences and Technology at the State University of Paraná - Campus of Cascavel.

Prior to sowing of baby corn and ARS application (beginning of the experiment), soil samples were collected with the aid of a dutch auger, at depths of $0-20,20-40$ and $40-60 \mathrm{~cm}$, and then homogenized. Results obtained were considered for characterization of the area and as the first soil sampling. Halfway through the cycle (approximately 40 days after sowing - DAS) and at end of the experiment (70 DAS - 100\% of crop cycle) two additional soil samplings were performed, totaling 72 soil samples in three stages (beginning, middle and end of the experiment) at a depth of $0-60 \mathrm{~cm}$.

After testing for normality and homogeneity of variances (Minitab ${ }^{\circledR}$ 14), parameters without normal distribution were transformed according to Banzatto and Kronka (2006), and then subjected to analysis of variance (Sisvar ${ }^{\circledR}$ ). The Tukey test at $5 \%$ probability was used for significant interactions and the regression analysis was performed for foliar concentrations.

\section{RESULTS AND DISCUSSION}

Summaries of the analyses of variance for foliar concentrations of macro and micronutrients in the baby corn culture treated with swine wastewater alone and combined with chemical fertilizer are presented in Table 3, where the occurrence of significant interaction effects between ARS x AD are observed only for $\mathrm{N}$ and $\mathrm{P}$.

Table 3. F values for average applications of swine wastewater (ARS) and nitrogen (AD) on the macronutrient $\left(\mathrm{g} \mathrm{kg}^{-1}\right)$ and micronutrients $\left(\mathrm{mg} \mathrm{kg}^{-1}\right)$ contents in the leaves of baby corn

\begin{tabular}{|c|c|c|c|c|c|c|}
\hline \multirow{2}{*}{ Variation causes } & \multicolumn{6}{|c|}{$\mathrm{F}$ values } \\
\hline & $\mathrm{N}$ & $\mathrm{P}$ & K & $\mathrm{Ca}$ & $\mathrm{Mg}$ & $\mathrm{S}$ \\
\hline ARS & $17.16^{*}$ & $4.12 *$ & $4.11^{*}$ & $1.03^{\text {ns }}$ & $6.09 *$ & $2.29^{\mathrm{ns}}$ \\
\hline $\mathrm{AD}$ & $3.54^{\mathrm{ns}}$ & $0.77^{\mathrm{ns}}$ & $1.13^{\text {ns }}$ & $0.54^{\text {ns }}$ & $0.18^{\mathrm{ns}}$ & $0.38^{\mathrm{ns}}$ \\
\hline ARS x AD & $2.91^{*}$ & $3.30^{*}$ & $0.07^{\text {ns }}$ & $0.06^{\mathrm{ns}}$ & $1.01^{\mathrm{ns}}$ & $0.11^{\mathrm{ns}}$ \\
\hline Mean & 16.23 & 4.13 & 11.27 & 6.76 & 2.58 & 3.61 \\
\hline \multirow{2}{*}{\multicolumn{2}{|c|}{ Variation causes }} & \multicolumn{5}{|c|}{$\mathrm{F}$ values } \\
\hline & & $\mathrm{Cu}$ & \multicolumn{2}{|c|}{$\mathrm{Zn}$} & $\mathrm{Mn}$ & $\mathrm{Fe}$ \\
\hline \multicolumn{2}{|c|}{ ARS } & $0.78^{\mathrm{ns}}$ & \multicolumn{2}{|c|}{$0.49^{\mathrm{ns}}$} & $8.10^{*}$ & $3.22 *$ \\
\hline \multicolumn{2}{|c|}{$\mathrm{AD}$} & $0.009^{\mathrm{ns}}$ & \multicolumn{2}{|c|}{$0.18^{\mathrm{ns}}$} & $3.91^{\mathrm{ns}}$ & $0.44^{\text {ns }}$ \\
\hline \multicolumn{2}{|c|}{ ARS x AD } & $0.96^{\mathrm{ns}}$ & \multicolumn{2}{|c|}{$0.05^{\mathrm{ns}}$} & $2.07^{\mathrm{ns}}$ & $1.95^{\text {ns }}$ \\
\hline \multicolumn{2}{|c|}{ Mean } & 8.11 & \multicolumn{2}{|c|}{37.91} & 18.50 & 51.54 \\
\hline
\end{tabular}

ns: not significant at 5\% probability * significant at 5\% probability. For normalization of variables, values were $\sqrt{x+1}$ transformed (BANZATTO and KRONKA, 2006), except for K, Ca, Mn and Fe (Data Normality - Shapiro Wilk test and homoscedasticity). 
It can be observed that the average contents of $\mathrm{N}$ and $\mathrm{K}$ (Table 3 ) are below those considered adequate (27.5 to $32.5 \mathrm{~g} \mathrm{~kg}^{-1}$ and 17.5 to $22.5 \mathrm{~g} \mathrm{~kg}^{-1}$, respectively) and the nutrients $\mathrm{P}, \mathrm{Ca}, \mathrm{Mg}$ and $\mathrm{S}$ are well above the appropriate values ( 2.5 to $3.5,2.5$ to $4.0,2.5$ to 4.0 and 1.0 to $2.0 \mathrm{~g} \mathrm{~kg}^{-1}$, respectively) for the maize crop (BÜLL, 1993). Thus, it can be inferred that applications of ARS and $\mathrm{AD}$ were sufficient to meet the nutritional requirements of $\mathrm{P}$, $\mathrm{Ca}, \mathrm{Mg}$ and $\mathrm{S}$ for maize plants.

Prior (2008) evaluated the effect of swine wastewater in soil and maize and also found values for $\mathrm{N}$ below those considered ideal for crop development, on average reaching $15.02 \mathrm{~g} \mathrm{~kg}^{-1}$. For $\mathrm{P}$ and $\mathrm{K}$ the same author obtained average values of 0,027 and $0,25 \mathrm{~g} \mathrm{~kg}^{-1}$, below those suitable for $\mathrm{P}$ and $\mathrm{K}$, differing from the present study which showed contents of $\mathrm{P}$ and $\mathrm{K}$ above and below the adequate values, respectively. This may be explained by the difference in nutrients applied via ARS compared to the study Prior (2008) or also by the input and accumulation of phosphorus, which is readily immobilized, and low P mobility in soil (COSTA et al., 2009).

In this context the high mobility of phosphorus within the plant, which in different conditions of availability (BÜLL, 1993), may promote different responses in $\mathrm{P}$ accumulation in the plant as well as $\mathrm{P}$ compartmentalization in the shoots. About twothirds of phosphorus present in liquid swine manure is found in the water insoluble form, forming organic structures which generate residual effects in the manure as observed by Ceretta et al. (2003);

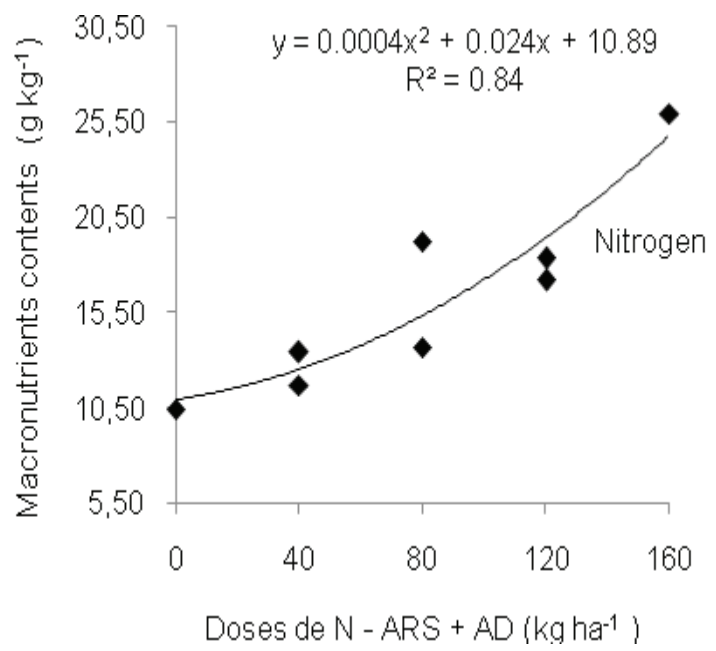

and frequent manure applications can also cause $\mathrm{P}$ accumulation in soil, a fact observed in this study.

Most $\mathrm{N}$ available to crops comes from the interaction between nitrogen fertilization and mineralization/immobilization of $\mathrm{N}$ from crop residues and $\mathrm{N}$ from soil organic matter (SILVA et al., 2008). The low nitrogen content observed is partially justified by the fact that baby corn was cultivated in succession with black oats, which results in lower yields of dry matter and lower nitrogen absorption (AITA et al., 2006).

The interaction between nitrogen and potassium is antagonistic, because potassium affects nitrate uptake and its reduction in plant tissues (MALAVOLTA et al., 1997). In general, nitrogen is the nutrient which provides the greatest increases in productivity; however, elevated applications with no corresponding increase in potassium can result in inadequate $\mathrm{N}: \mathrm{K}$ ratios in the plant.

Levels of calcium and sulfur found in baby corn leaves were not affected in the treatments with increasing doses of $\mathrm{ARS}$ and $\mathrm{AD}$, showing similar behavior to $\mathrm{P}$ and $\mathrm{Mg}$, ie, their contents exceeded appropriate levels. The N:S ratios in the plant between 8 and 12:1 (MALAVOLTA, 2006) are considered ideal, and in this study ratios of 4 to $7: 1$ were established. According to the results presented (Figure 1), the accumulation of nitrogen and phosphorus in baby corn plants presented quadratic behavior, with an increasing trend and coefficients of determination $\left(\mathrm{R}^{2}\right)$ of 0.84 and 0.49 , indicating good and low relationship between variables, respectively.

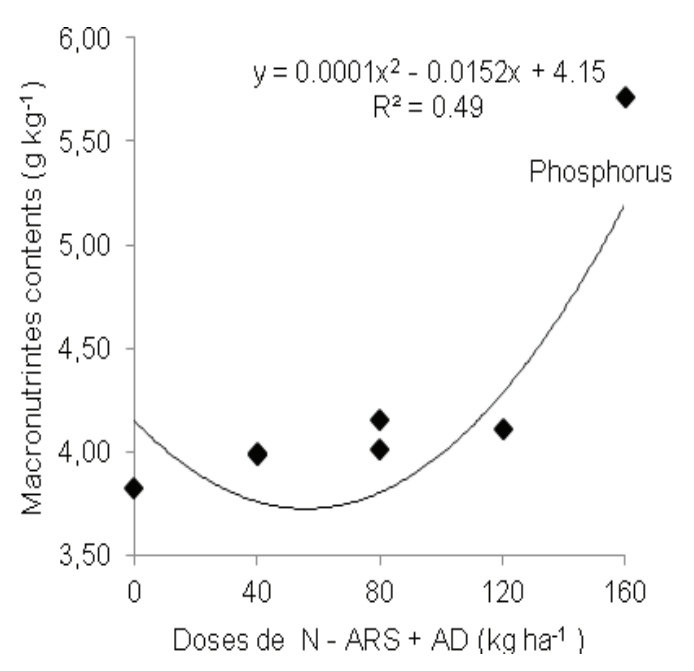

Figure 1. Average accumulation of nitrogen and phosphorus in baby corn leaves as a function of swine wastewater application (ARS) combined with nitrogen fertilization (AD), Cascavel - PR, 2008. 
Increased levels of ARS application resulted in elevated nitrogen and phosphorus contents with values being significant depending on the ARS. Nitrogen deficient plants present low nitrogen levels and increased phosphorus, potassium, calcium, magnesium and sulfur (MALAVOLTA, 2006), because concentrations are below levels considered adequate. The concentrations of macronutrients in baby corn plants showed the following order: $\mathrm{N}>$ $\mathrm{K}>\mathrm{Ca}>\mathrm{P}>\mathrm{S}>\mathrm{Mg}$ at sampling.

Concentrations of micronutrients (Table 3) were within the range considered adequate by Büll (1993). According to this author, maize plants should contain $6-20 \mathrm{mg} \mathrm{kg}^{-1}, 20$ to $70 \mathrm{mg} \mathrm{kg}^{-1}, 20$ to $150 \mathrm{mg} \mathrm{kg}^{-1}$ and $20-250 \mathrm{mg} \mathrm{kg}^{-1}$ of $\mathrm{Cu}, \mathrm{Zn}, \mathrm{Mn}$ and $\mathrm{Fe}$, respectively.

Concentrations of micronutrients in babycorn plants presented the following order when sampled: $\mathrm{Fe}>\mathrm{Mn}>\mathrm{Zn}>\mathrm{Cu}$. Authors reported increases in $\mathrm{Zn}$ concentration in parts of corn grown in soil treated with residues, highlighting the study of Nogueira et al. (2008) who applied cumulative doses of 45, 90 and $127 \mathrm{t} \mathrm{ha}^{-1}$ of sewage sludge for nine consecutive years. The low values found for $\mathrm{Cu}$ in this research can be justified by the high $\mathrm{N}$ supply, which reduces $\mathrm{Cu}$ availability in plants (KIRKBY; RÖMHELD, 2007). Martins et al. (2003) found that the concentrations of $\mathrm{Mn}$ and Fe were reduced due to the high $\mathrm{N}$ supply, but $\mathrm{Cu}$ concentrations remained constant.

According to the results (Figure 2), accumulation of manganese and iron in baby corn plants showed quadratic behavior, with a decreasing trend for $\mathrm{Mn}$ and increase for $\mathrm{Fe}$, and coefficients of

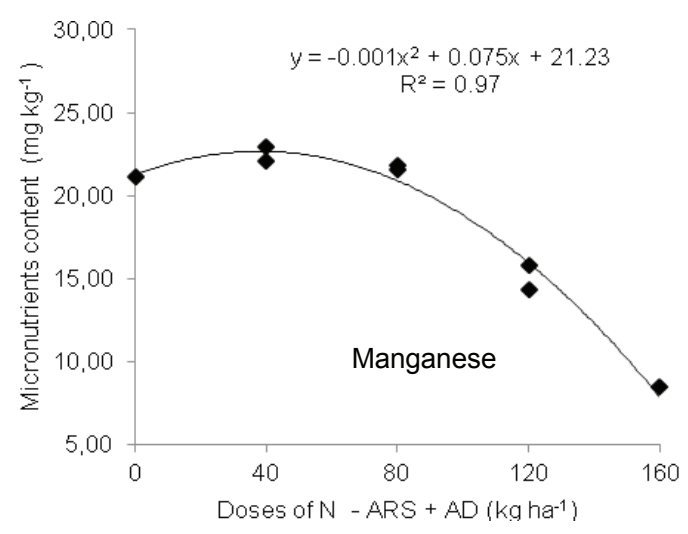

determination $\left(\mathrm{R}^{2}\right)$ of 0.97 and 0.67 , indicating high and good relationship among variables, respectively (BANZATTO; KRONKA, 2006).

The Fe content was higher than contents of the other micronutrients. Suggesting little reduction of nitrite and sulfite, so that nitrate and sulfate are often present at low levels in plants well supplied with Fe (KIRKBY; RÖMHELD; 2007).

Soil acidification increases availability of the micronutrients $\mathrm{Cu}, \mathrm{Mn}, \mathrm{Fe}$ and $\mathrm{Zn}$ (KIRKBY; RÖMHELD, 2007), which differed from this work only in relation to the $\mathrm{Mn}$ content, since $\mathrm{Cu}, \mathrm{Zn}$ and $\mathrm{Fe}$ contents increased as a function of increased acidity.

Summaries of the analyses of variance for soil chemical attributes in treatments with swine wastewater applied alone and combined with nitrogen fertilization are presented in Table 4 (only significant results).

There was no significant effect at $5 \%$ probability for the ARS x AD interaction with respect to the evaluated parameters. However, there was a significant difference for $\mathrm{pH}$, potential acidity $\left(\mathrm{H}+\mathrm{A} \ell^{+3}\right)$ and saturation $(\mathrm{V})$ at $5 \%$ for nitrogen fertilization (AD) at 70 DAS and for potassium (K) at $40 \mathrm{DAS}$, and for K at $40 \mathrm{DAS}$ and $70 \mathrm{DAS}$, there was significance for ARS.

According to the Tukey test results, the $\mathrm{pH}$ varied significantly only in soils receiving nitrogen, ie, no direct influence of swine wastewater was observed in these data. Ceretta et al. (2003) evaluated the chemical properties of soil submitted to application of treated wastewater, screened swine wastewater, swine and poultry manure and liquid swine manure, respectively, also observed the same effect.

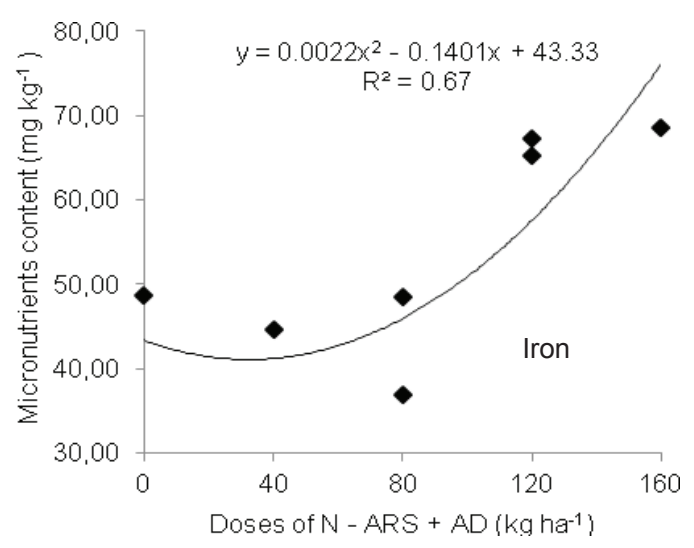

Figure 2. Average accumulation of manganese and iron by leaves of baby corn as a function of swine wastewater application (ARS) combined with nitrogen (AD) fertilization, Cascavel - PR. 
Table 4. Results of the mean comparison test for $\mathrm{pH}$, potential acidity $\left(\mathrm{H}+\mathrm{A} \ell^{+3}\right)$, base saturation $(\mathrm{V})$ and potassium $(\mathrm{K})$ in treatments with increasing doses of swine wastewater alone and with combined application with nitrogen at 40 and 70 days after sowing (DAS). Cascavel - PR (2008)

\begin{tabular}{|c|c|c|c|c|c|}
\hline \multicolumn{6}{|c|}{70 DAS } \\
\hline \multirow{2}{*}{$\begin{array}{l}\text { Fertilization } \\
\qquad\left(\mathrm{kg} \mathrm{ha}^{-1}\right)\end{array}$} & \multicolumn{4}{|c|}{ Dose of swine wastewater $\left(\mathrm{kg} \mathrm{ha}^{-1}\right)$} & \multirow[t]{2}{*}{ Means } \\
\hline & 0 & $40(115.20)^{*}$ & $80(230.40)^{*}$ & $120(345.60)^{*}$ & \\
\hline 0 & 6.26 & 6.33 & 6.46 & 6.43 & $6.37 \mathrm{~B}$ \\
\hline 40 & 6.36 & 5.83 & 6.00 & 6.13 & $6.08^{\mathrm{a}}$ \\
\hline \multirow[t]{3}{*}{ Means $(\mathrm{pH})^{*}$} & 6.31 & 6.08 & 6.23 & 6.28 & \\
\hline & 3.15 & 3.04 & 2.82 & 2.67 & $2.92 \mathrm{a}$ \\
\hline & 2.96 & 4.17 & 3.70 & 3.18 & $3.50 \mathrm{~B}$ \\
\hline \multirow[t]{3}{*}{ Means $\left(\mathrm{H}^{+}+\mathrm{A} \ell^{+3}\right)^{*}$} & 3.06 & 3.61 & 3.26 & 2.92 & \\
\hline & 71.34 & 72.67 & 74.44 & 76.06 & 73.63B \\
\hline & 74.59 & 60.00 & 65.74 & 70.89 & $67.80 \mathrm{a}$ \\
\hline Means (V\%) & 72.97 & 66.33 & 70.09 & 73.47 & \\
\hline \multicolumn{6}{|c|}{40 DAS } \\
\hline & 0.14 & 0.22 & 0.37 & 0.60 & $0.33 \mathrm{a}$ \\
\hline & 0.27 & 0.39 & 0.53 & 0.58 & $0.44 \mathrm{~B}$ \\
\hline Means $(\mathrm{K})^{*}$ & $0.20^{\mathrm{a}}$ & $0.30 \mathrm{ab}$ & $0.45 \mathrm{bc}$ & $0.59 \mathrm{c}$ & \\
\hline \multicolumn{6}{|c|}{70 DAS } \\
\hline & 0.13 & 0.15 & 0.29 & 0.46 & 0.26 \\
\hline & 0.18 & 0.42 & 0.43 & 0.50 & 0.38 \\
\hline Means (K) & $0.16 a$ & $0.28 \mathrm{ab}$ & $0.36 \mathrm{ab}$ & $0.48 \mathrm{ab}$ & \\
\hline
\end{tabular}

$* \mathrm{H}^{+}+\mathrm{Al}^{+3}$ and $\mathrm{K}\left(\mathrm{cmol}_{\mathrm{c}} \mathrm{dm}^{-3}\right) ; \mathrm{pH}$ in $\mathrm{CaC}_{2}$

It was further found that the highest and lowest mean values for soil $\mathrm{pH}$ were 5.83 and 6.46, respectively, and values decreased from 6.37 to 6.08 with increasing AD doses (Table 4). Mattias et al. (2010) observed average $\mathrm{pH}$ values between 5.1 and 5.5 in soils receiving applications of swine slurry, therefore differing from this work, where changes in $\mathrm{pH}$ were a function of $\mathrm{AD}$ doses and not manure application. The potential acidity $\left(\mathrm{H}+\mathrm{A} \ell^{+3}\right)$ showed inverse behavior to $\mathrm{pH}$ at the sampled depths, in which there was an increase in potential acidity with increasing doses of $\mathrm{AD}\left(2.92\right.$ and $3.50 \mathrm{cmol}_{\mathrm{c}}$ $\mathrm{dm}^{-3}$ - Table 4). Such increases in potential acidity are attributed to $\mathrm{N}$ fertilization, in which the highest and lowest average values were 2.67 and $4.17 \mathrm{cmol}_{c}$ $\mathrm{dm}^{-3}$, respectively. Contrary to this work, Silva et al. (2008) observed decreases in potential acidity when applying animal manure combined with mineral fertilizer, and attributed it to the mineral fertilization.
Base saturation (V\%) decreased with increasing doses of $\mathrm{AD}$ (73.63 to $67.80 \%)$ and presented similar behavior for $\mathrm{pH}$. Queiroz et al. (2004) applied liquid swine manure to Red Yellow Podzolic and found increases in acidity, sum of bases, CEC and decreased base saturation. Higher doses of ARS and AD resulted in higher concentrations of potassium, and these were significantly affected at 40 DAS. Only the ARS influenced the levels found in soil at 70 DAS.

The average $\mathrm{K}$ concentrations for increasing doses of ARS increased at 40 DAS $(0.20,0.30,0.45$ and $0.59 \mathrm{cmol}_{\mathrm{c}} \mathrm{dm}^{-3}-$ Table 4 ), with similar behavior for $\mathrm{AD}$ doses, where the highest dosage showed the highest means ( 0.33 and $\left.0.44 \mathrm{cmol}_{\mathrm{c}} \mathrm{dm}^{-3}\right)$.

At 70 DAS, $\mathrm{K}$ concentrations suffered significant influence of only increasing ARS doses, and means differed only from the concentration that did not receive ARS.

\section{REVENG}

$$
\text { 574-582p. }
$$

ENGENHARIA NA AGRICULTURA, VIÇOSA - MG, V.21 N.6, NOVEMBRO / DEZEMBRO 2013 
Queiroz et al. (2004) evaluated the effect of liquid swine manure for four months on the average equivalent of $800 \mathrm{~kg} \mathrm{ha}^{-1}$ day $^{-1}$ of biochemical oxygen demand and observed potassium accumulation in the soil. Assmann et al. (2009) also found $\mathrm{K}$ accumulation with application of $120 \mathrm{~m}^{3} \mathrm{ha}^{-1}$ of swine slurry. In the study of Prior (2008), average values ranged from 1.34 to 3.70 $\mathrm{cmol}_{\mathrm{c}} \mathrm{dm}^{-3}$, while in this work values were 0.13 to $0.60 \mathrm{cmol}_{\mathrm{c}} \mathrm{dm}^{-3}$. Elevated contents, although potassium is considered a relatively mobile cation in the soil, may have been influenced by the period of low rainfall, aiding to prevent leaching and $\mathrm{K}$ accumulation in soil.

\section{CONCLUSIONS}

From the results obtained, considering the sixth cycle of wastewater application associated with nitrogen fertilization at the experimental location and conditions, it was concluded that:

- The ARS doses are less than $345 \mathrm{~m}^{3} \mathrm{ha}^{-1}$ when applied alone or, when combined with $\mathrm{AD}$ must be less than $120 \mathrm{~kg} \mathrm{ha}^{-1}$ of $\mathrm{N}$ because systematic use elevated the levels of plant nutrients $(\mathrm{P}, \mathrm{Ca}$, $\mathrm{Mg}$ and $\mathrm{S}$ ), which can reach levels above those recommended, suggesting their accumulation;

- $\quad$ The AD dose $\left(40 \mathrm{~kg} \mathrm{ha}^{-1}\right)$ resulted in increased soil chemical properties for $\mathrm{H}+\mathrm{A}^{+3}, \mathrm{CTC}, \mathrm{V}$, $\mathrm{P}, \mathrm{K}, \mathrm{Ca}$ and $\mathrm{Mg}$, and decreases in $\mathrm{pH}$;

- It should be noted that application depends on the concentration of nitrogen in the ARS, a fact not considered by the farmer who always refers to the application volume and not the concentration.

\section{REFERENCES}

AITA, C.; CHIAPINOTTO, I.C.; GIACOMINI, S.J.; HÜBNER, A.P.; MARQUES, M.G. Decomposição de palha de aveia preta e dejetos de suínos em solo sob plantio direto. Revista Brasileira de Ciência do Solo, Viçosa, v.30, p.149-161, 2006.

ASSMANN, J.M.; BRAIDA, J.A.; CASSOL, L.C.; MAGIERO, E.C.; MANTELI, C.; GRIZ, E. Produção de matéria seca de forragem e acúmulo de nutrientes em pastagem anual de inverno tratada com esterco líquido de suínos. Ciência Rural, Santa Maria, v.39, p.2408-2416, 2009.

BANZATTO, D.A.; KRONKA, S.N. Experimentação agrícola. 3 ed. Jaboticabal: Funep. 247p. 2006.

BARROS, F.M.; MARTINEZ, M.A.; NEVES, J.C.L.; MATOS, A.T.; SILVA, D.D. Características químicas do solo influenciadas pela adição de água residuária da suinocultura. Revista Brasileira de Engenharia Agrícola e Ambiental, Campina Grande, v.9, p.47-51, 2005.

BAUMGARTNER, D.; SAMPAIO, S.C.; SILVA, T.R.; TEO, C.R.P.A.; VILAS BOAS, M.A. Reuso de águas residuárias da piscicultura e da suinocultura na irrigação da cultura da alface. Engenharia Agrícola, Jaboticabal, v.27, p.152163, 2007.

BORGES, I.D. Marcha de absorção de nutrientes e acúmulo de matéria seca em milho. 2006, 132f. Tese (Doutorado em Fitotecnia). Universidade Federal de Lavras, Lavras. 2006.

BRANDJES, P.J.; WIT, J.; MEER, H.G.V.D.; KEULEN, H.V. Livestock and the environment: finding a balance. Wageningen: IAC, 1996. 53p.

BÜLL, L.T. Nutrição mineral do milho. In: BÜLL, L.T.; CANTARELLA, H. Cultura do milho: fatores que afetam a produtividade. Piracicaba: Associação Brasileira para Pesquisa da Potassa e do Fosfato, 1993. p.63-145.

CERETTA, C.A.; DURIGON, R.; BASSO, C.J.; BARCELLOS, L.A.R.; VIEIRA, F.C.B. Características químicas de solo sob aplicação de esterco líquido de suínos em pastagem natural. Pesquisa Agropecuária Brasileira, Brasília, v.38, p.729-735, 2003.

COSTA, F.X.; LIMA, V.A.; BELTRÃO, N.E.M.; AZEVEDO, C.V.; SOARES, F.A.L.; ALVA, I.D.M. Efeitos residuais de aplicação de biossólidos e da irrigação com água residuária no crescimento do milho. Revista Brasileira de Engenharia Agrícola e Ambiental, Campina Grande, v.13, p.687-693, 2009. 
FERREIRA, O.E.; BELTRÃO, N.E.M.; KÖNIG, A. Efeitos da aplicação de água residuária e nitrogênio sobre o crescimento e produção do algodão herbáceo. Revista Brasileira de Oleaginosas e Fibrosas, Campina Grande, v.9, p.893-902, 2005.

KIRKBY, E.A.; RÖMHELD, V. Micronutrientes na fisiologia de plantas: funções, absorção e mobilidade. Encarte Técnico, Informações Agronômicas 118. INPI, 24p. jun. 2007.

KONZEN, E.A.; ALVARENGA, R.C.; Adubação orgânica, sistemas de produção. 2008. Disponível em: http://sistemasdeprodução.cnptia.embrapa.br/ FontesHTML/Milho/CultivodoMilho/ferorganica. htm. Acesso em: 01 set. 2009.

MAGALHÃES, P.C.; DURÃES, F.O.M. Fisiologia da produção de milho. Circular Técnica 76. EMBRAPA Milho e Sorgo, Sete Lagoas, 10p. 2006.

MALAVOLTA, E. Manual de nutrição mineral de plantas. São Paulo: Agronômica Ceres, 2006. 631p.

MALAVOLTA, E.; VITTI, G.C.; OLIVEIRA, S.A. Avaliação do estado nutricional das plantas. 2 ed. Potafos: Piracicaba. 1997, 319p.

MARTINS, A.L.C.; BATAGLIA, O.C.; CAMARGO, O.A.; CANTARELLA, H. Produção de grãos e absorção de $\mathrm{Cu}, \mathrm{Fe}, \mathrm{Mn}$ e $\mathrm{Zn}$ pelo milho em solo adubado com lodo de esgoto, com e sem calcário. Revista Brasileira de Ciência do Solo, Viçosa, v.27, p.563-574, 2003.

MATTIAS, J.L.; CERETTA, C.A.; NESI, C.N.; GIROTTO, E.T.; TRENTIN, E.E.; LOURENZI, C.R.; VIEIRA, R.C.B. Cupper, zinc and manganese in soil of two watersheds in Santa Catarina with intensive use of pig slurry. Revista Brasileira de Ciência do Solo, Viçosa, v.34, p. 1445-1454, 2010.

NOGUEIRA, T.A.R.; OLIVEIRA, L.R.; MELO, W.J.; FONSECA, I.M.; MELO, G.M.P.; MELO, V.P.; MARQUES, M.O. Cádmio, cromo, chumbo e zinco em plantas de milho e em latossolo após nove aplicações anuais de lodo de esgoto. Revista Brasileira de Ciência do Solo, Viçosa, v.32, p.2195-2207, 2008.
PANDOLFO, C.M.; CERETTA, C.A.; MASSIGNAM, A.M.; VEIGA, M.; MOREIRA, C.L. Análise ambiental do uso de fontes de nutrientes associadas a sistemas de manejo do solo. Revista Brasileira de Engenharia Agrícola e Ambiental, Campina Grande, v.12, p.543-550, 2008.

PLAZA, C.; HERNÁNDEZ, D.; GARCÍA-GIL, J.C.; POLO, A. Microbial activity in pig slurryamended soils under semiarid conditions. Soil Biollogy and Biochemistry, Brisbane, v.36, p.1577-1585, 2004.

PRIOR, M. Efeito da água residuária de suinocultura no solo e na cultura do milho. 2008. 111f. Tese (Doutorado em Agronomia). Universidade Estadual Paulista Júlio de Mesquita Filho, Botucatu. 2008.

QUEIROZ, F.M.; MATOS, A.T.; PEREIRA, O.G.; OLIVEIRA, R.A. de; Características químicas de solo submetido ao tratamento com esterco líquido de suínos e cultivado com gramíneas forrageiras. Ciência Rural, Santa Maria, v.34, p.1487:1492, 2004.

SHEN, Q.R.; SHEN, Z.G. Effects of pig manure and wheat straw on growth of mung bean seedlings grown in aluminium toxicity soil. Bioresource Technology, Madison, v.76, p.235-240, 2001.

SILVA, E.C.; MURAOKA, T.; BUZETTI, S.; CONTRERAS, S.F.; TRIVELIN, P.C.O. Utilização do nitrogênio da palha de milho e adubos verdes pela cultura do milho. Revista Brasileira de Ciência do Solo, Viçosa, v.32, p.2853-2861, 2008.

SMANHOTTO, A.; SOUSA, A.P.; SAMPAIO, S.C.; NÓBREGA, L.H.P.; PRIOR, M.; Cobre e zinco no material percolado e no solo com a aplicação de água residuaria de suinocultura em solo cultivado com soja. Engenharia Agrícola, Jaboticabal, v.30, p.347-357, 2010.

TEDESCO, M.J.; GIANELLO, C.; BISSANI, C.A.; BOHENEN, H.; VOLKWEISS, S.J. Análise de solo, plantas e outros materiais. 2. ed. Porto Alegre: Universidade Federal do Rio Grande do Sul, 1995. 174p. 